\title{
ROLE OF EMPLOYEE BEHAVIOUR AND JOB STRESS ON WORK-LIFE BALANCE: A CASE OF HEIS OF PAKISTAN
}

\section{Sofia Bano ${ }^{1}$ and Abuzar Wajidi ${ }^{2}$}

\begin{abstract}
The study aims to identify how workplace stress and employee behavior impair the work-life balance of faculty members of Higher Education Institutes in Karachi, Pakistan. This study has included a quantitative survey research design. The study collected 386 sample responses from faculty members using the purposive sampling technique. The PLS-SEM analysis was used for data analysis through SmartPLS version 3.2.9. The results have shown that employee behavior has a positive and significant effect on ER, IR, and WLB; workplace stress has a positive and significant effect on anxiety; workplace stress has a positive and significant effect on time stress, and workplace stress has a negative and significant effect on work-life balance. Furthermore, the study recommends using person-centered stress management techniques for possible work-life stress and employee well-being. Offering relaxation/care exercise classes, enabling wellness, and supplying facilities, such as gymnasiums, encouraging safe living, healthy eating options, and providing guidance are just a few examples. This study is significant for employee's well-being because the findings will allow them to understand and negotiate their roles throughout the family and work-life. By understanding the importance of WLB, employees would be able to introspect themselves to cope with their job and relationship management. Similarly, management can identify career stages and help employees with the development tasks they experience at each stage. Lastly, the study implications accentuate that by formulating appropriate strategies, management can help employees and retain them as essential organizational assets.
\end{abstract}

Keywords: Work-Life Balance; Employee Behavior; Job Stress; Higher Education Institutes; PLS-SEM Analysis.

${ }^{1}$ PhD Scholar, University of Karachi, Karachi, Pakistan. Email: sofiashaikh@hotmail.com

2 Dean, Faculty of Management Sciences, Barrett Hodgson University, Karachi, Pakistan. Email: abuzar_wajidi@hotmail.com 


\section{INTRODUCTION}

Due to the increased reach of work; increasing job demands and job stress have become a big problem recently. In the workplace, longer working hours and increased job responsibilities are becoming progressively more frequent. There are more single-parent families, dual-career families, and working individuals who are the breadwinners for their elders and children, which necessitates family changes (Razak et al., 2014). Furthermore, work stress is produced by a worker's job requirements and demands being irrelevant or mismatched. Both employees and organizations understand job stress as a physical and psychological concept since it affects workers and leads to health issues and work-family conflict. Workplace stress causes high worker turnover, poor job quality, high absenteeism, and low productivity (Chang et al., 2017). Job stress is defined as a negative reaction that people have as a result of excessive demands or pressure placed on them at work. As a result, the elements that most affect job stress are work demand and time (Ayudhya et al., 2017). Employee behavior, on the other hand, is becoming progressively essential in a highly competitive workplace setting. Organizational citizenship conduct refers to an employee's positive behavior in the context of the organization. Employees are expected to assist their coworkers with job responsibilities, stay late at work and participate in extracurricular activities, and volunteer to teach newcomers (Ghosh, 2016). Employee performance and organizational effectiveness can both be hindered by excessive levels of stress (Husin et al., 2017). The relationship between stress and employee performance has been widely investigated since it leads to decreased willingness and poor work performance.

Although workplace stress is not a new issue in the literature, it remains a vital research area due to unpredictable economic situations, limited precious resources, severe competition, human rights, and WLB (Selye, 1956; Yao et al., 2014). Work-life balance influences people's expectations of how well the work and non-work obligations fit together and are managed by their life values, ambitions, and goals framework (Haar et al., 2019). Stress management has become a major problem for both individuals and businesses in recent years. A recent study has underlined the need of understanding the implications and repercussions of workplace stress, which eventually affects WLC, individual well-being, and organizational performance in the wider context (Gillespie et al., 2001; Hayes et al., 2015; Karkoulian et al., 2016; Razak et al., 2014; Ross \& Vasantha, 2014). Because of the rapid economic development and large population, Asian 
employment accounts for a significant percentage of the worldwide working population, highlighting the importance of Asian economies for research and practice. Despite the growth in longitudinal studies on work-life research in the West, the Asian population has paid less attention to this field of study (Le et al., 2020). Furthermore, recent empirical and theoretical research supports the assertion that workplace stress and employee behavior have significant implications for WLB (Razak et al., 2014; Singh, 2013; Yadav \& Yadav, 2014). Employee behavior is also influenced by unconventional work settings, lack of peer and supervisory support, long working hours, and poor motivation perspectives at work (Colligan \& Higgins, 2006; Ferguson, 2012; Othman et al., 2014; Rahimić et al., 2012; Yao et al., 2014).

Although empirical research has made significant contributions in this area, there has been a shortage of current research on the link between workplace stress, employee behavior, and WLB. In the setting of HEI in Karachi, Pakistan, the current study has gone through the process of conducting and recognizing the necessity of investigating the imperatives of workplace stress and employee behavior toward work-life balance.

\section{LITERATURE REVIEW}

\section{Conservation of Resources Theory}

The COR (Niessen et al., 2017) concept is based on the idea that people fight to acquire, maintain, develop, and safeguard the things they value most (Brotheridge \& Lee, 2002). The COR theory proposes the idea that intelligence has a natural growth and partiality, with the loss of resources being strongly weighted and resource gains being lightly weighted (Freedy \& Hobfoll, 1994). Regarding this, according to Hobfoll (2001) the COR, pressure occurs when (a) the primary resource is threatened, (b) the main resource is lost, or (c) the main resource is not acquired despite substantial efforts. The COR theory is essentially a motivational theory that elucidates how individuals behave in response to the evolutionary necessity to gain and defend the resources required to survive, a behavior that is linked to human genetics. Obtaining and safeguarding the unique strengths and ties of society are human characteristics, just as they are for social animals (Hobfoll, 2011). Humans, on the other hand, are capable of devising methods to ensure their survival, and having effective communication tools is a distinct advantage that aids social bonding 
and survival. As a result, humans have a valuable tool that not only aids in stress management but also allows them to save aside resources for future needs.

Besides, COR theory refers to acquiring and maintaining the resources along with gaining more resources as well. This theory is linked with the current conceptual framework as when the workplace stress is reduced then the employees could gain WLB and acquire different resources. Similarly, when stress is reduced then the employees can reduce their turnover intentions and become conserved in their current organizations. Additionally, employee behavior is related to this theory as the behavior should be positive and it can eventually enhance the attitude to create a WLB. Hence, the desire to accomplish or gain WLB in their organization is the presence of conserving or using resources along with aiming for additional resources as well.

\section{Workplace Stress/Job Stress and WLB}

In a pressure work environment and stressful routine, the chances of reduction in job satisfaction, organizational commitment, and increase in burnout are high (Silva et al., 2021). According to Senol-Durak et al. (2021) increase in the level of stress is equal to a lack of wellbeing, specifically when a person lacks to achieve effective strategies in order to cope up with the stress.

In Pakistani universities, Chaudhry (2012) looked into the relationship between occupational stress and diversity. The outcomes of the study revealed substantial differences in reported stress levels among faculty members of various age groups. Giauque et al. (2019), investigated whether employment opportunities have an impact on employee stress and turnover intentions in professional intergovernmental organizations. They contextualized the job resources and needs model within the diverse working contexts of global corporations. Similarly, the influence of workload, WLB, and autonomy on teacher job performance was investigated by Johari, Tan, and Zulkarnain (2017). According to the findings, participants' work performance was affected by autonomy and WLB. On the other side, there was no noticeable impact of school teachers' workload on job performance. Duong et al. (2020) Investigated the challenges that women working in multinational businesses in Vietnam confront when it comes to the advantages of work-life balance. The goal of the study was to uncover the factors that impact female employees who deal with work-life balance issues. Noor (2011) Investigated the relationship between academics in Malaysian public higher education's WLB satisfaction and their intention to leave. The findings revealed that perceived WLB satisfaction was linked to unfavorable intentions to leave the 
company. Kumari (2012) also assessed WLB based on employee perceptions and their relationship with work satisfaction. There was a significant difference between male and female respondents' views of certain WLB variables. In Pakistan's cultural and socioeconomic context, Rehman and Azam Roomi (2012) looked at many elements that influence women's family roles and jobs. The findings of the study revealed that WLB was a key factor among numerous others when it came to launching a new business.

Job satisfaction, organizational commitment, and burnout are all likely to decrease in a highpressure work environment and stressful routine (Dryson et al., 1996). According to (Kundaragi \& Kadakol, 2015), an increase in stress level equals to the lack of well-being, particularly when a person is unable to develop appropriate stress-coping methods (Miller et al., 2008). Non-work outcomes including family performance and leisure, as well as marital and family satisfaction are connected to lower levels of WLC and WLB happiness (Armstrong et al., 2015; Saeed \& Farooqi, 2014). As per the statement of Neumann et al. (2017) stress at work is connected to perceived threats and demands at work, or it is comparable to an employee's unpleasant job experience. Therefore, we hypothesize that:

\section{H1: Workplace stress has a significant effect on WLB.}

\section{Employee Behavior and WLB}

Using logistic regression models, Wirtz et al. (2011) looked at the link between working Sundays and WLB. According to research, serving on one or two Sundays each month is linked to an elevated risk of health impairment. Although working on Saturdays has grown more popular, working on Sundays may have a detrimental impact on employees' WLB. Chawla and Sondhi (2011) investigated WLB as a source of concern and research for both the organization and people. Job autonomy, organizational commitment, and perceived work are all major contributors for workers, according to the findings. In East Malaysia, Thamrin and Riyanto (2020) looked at the influence of work-life balance practices on employee performance (EP) and the mediating role of job stress (JS) in the link between WLB practices and EP among doctors and nurses. The impact of stress on job performance was also investigated by Warraich et al. (2014) in the context of workers. Worker stress is triggered by task tension, workload, and insufficient supervisor pay, according to the research, and this stress lowers productivity and performance. In the United Arab 
Emirates, Gudep (2019) looked at the connections between FWS, OC, WLB, and JS for teachers in UAE.

Previous studies have looked at this possibility, and the findings revealed that WLB has a favorable relationship with employee performance as well as organizational performance (McCarthy et al., 2010). Furthermore, this favorable relationship had several significant outcomes, such as lower staff turnover, improved performance, and increased work satisfaction (Ahmad et al., 2015). It also improves in-role performance, which is when an employee is assigned a specific duty to accomplish and completes it with more precision (Annink et al., 2016). The better psychological experience and the employee's well-being help in doing the work with more concentration, resulting in improved performance (Armstrong et al., 2015; Lestari \& Rizkiyah, 2021). Employees who have had a better psychological experience and are happier in their lives are more likely to execute their work with more attention, which leads to improved performance (Armstrong et al., 2015). Also, the problems and tensions that emerge in the work-family partnership, according to Direnzo et al. (2015), may have a damaging influence on the success of both in-role and out-ofrole workers. Therefore, this study hypothesized that:

H2: EB has a significant effect on WLB.

\section{CONCEPTUAL MODEL}

Figure 1. Research Framework

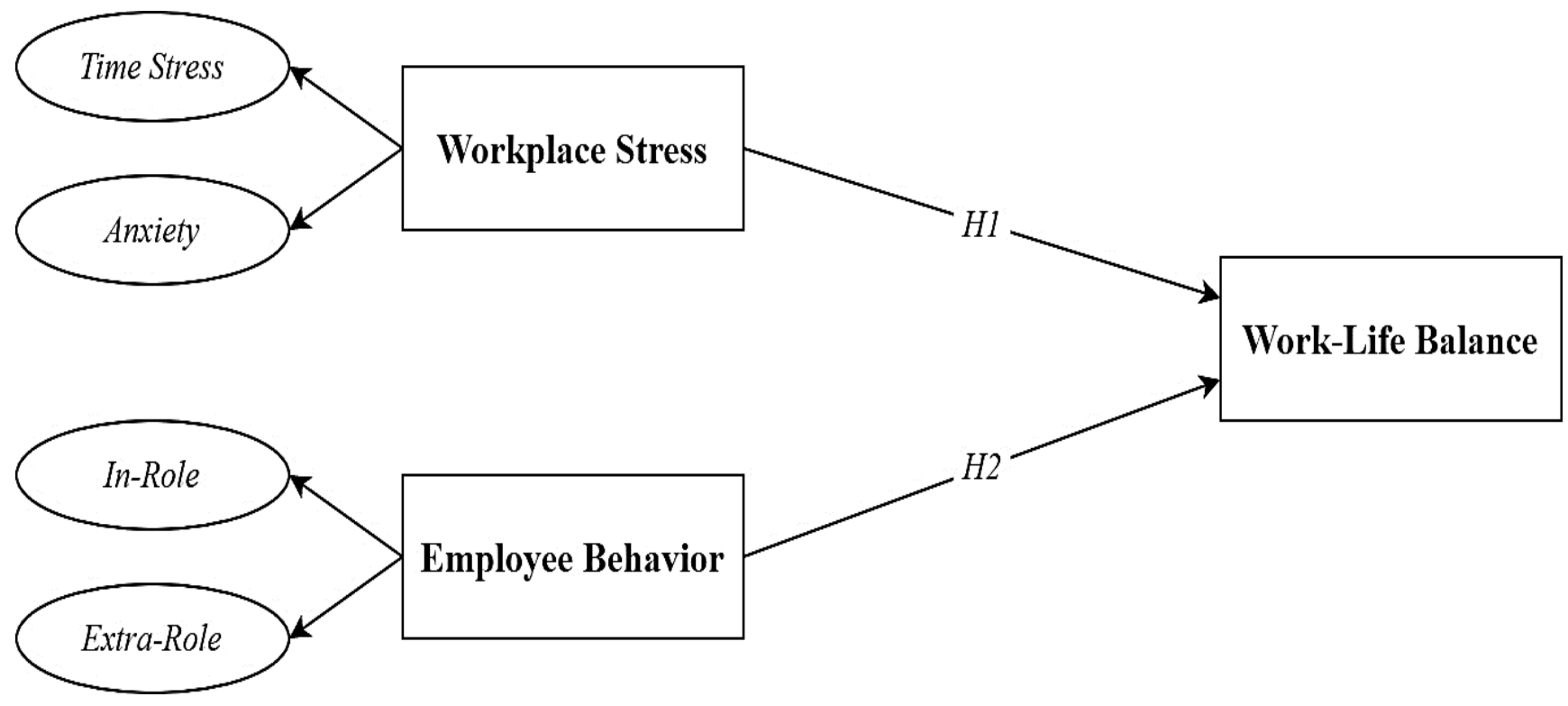

Source: Authors Contributions 


\section{METHODOLOGY}

Regular faculty (professors) at higher education institutions in Pakistan's Karachi region were the focus of the study. The study objective was to collect 384 survey responses from the target population for quantitative analysis with a 95 percent confidence interval. Following the sampling approach, a segment of the population was extracted to undertake research, the results of which may be generalized to some extent for the target population. The sampling technique is generally divided into two types: probability sampling and non-probability sampling (Kumar \& Phrommathed, 2005; Newman \& Benz, 1998). Convenience sampling in the non-probability sampling approach is the most often used data sampling method. It is a way for collecting data from a population that is accessible or close to the researcher and has an appropriate understanding of the study issue (Kumar \& Phrommathed, 2005; Newman \& Benz, 1998; Peffers et al., 2007). The non-probability purposive sampling is the sampling method used in this study. To collect the data, a quantitative close-ended questionnaire based on a five-point Likert scale rating was adapted from Schepers et al. (2012); Shukla \& Srivastava (2016). As the study was quantitative, data was gathered using survey questionnaires. The PLS-SEM is a more popular method for determining the cause and effect relationship between the study's variables (Hair et al., 2014). When compared to alternative approaches that do not incorporate cross-loadings and the HTMT ratio in the discriminant validity, using the PLS-SEM is much more beneficial (Henseler et al., 2015; Wong, 2013). When the link between the study variables is investigated, PLS-SEM also delivers reliable results (Hair et al., 2017; Hair et al., 2011). Thus, the PLS-SEM approach was used to analyze the data in this study.

Common Method Variance (CMV) is defined as a fictitious or inaccurate variance process that is connected to or caused by the measurement system and may be ascribed to specific systems that the measurements are supposed to reflect (Podsakoff et al., 2003). Harman's single-factor approach is used to diagnose CMV. As a result, the Harman single-factor approach was employed to diagnose CMV in this investigation. The measurements are incorporated into EFA in this approach to identify essential components that may aid in the discovery of variation in these measures (Krishnaveni \& Deepa, 2013). As a result, the total CMV of all measurements should be less than 50\%, as indicated by Krishnaveni and Deepa (2013); Podsakoff et al. (2003), and the study has 26.188 percent CMV. As a result, there was no indication of CMV in the research. 


\section{DATA ANALYSIS}

\section{Data Screening}

There were no missing values in the current dataset. The recommended threshold for detecting univariate outliers is through the standardized value $\mathrm{Z}$ score \pm 3.29 (Tabachnick \& Fidell, 2007). The sample size was 403 responses and there were no univariate outliers, so the sample size remained at 403 . The recommended threshold for detecting multivariate outliers is through Mahalanobis Distance D2 should be less than 0.001 (Tabachnick \& Fidell, 2007). As a result of the discovery of 17 multivariate outliers in this study, the final dataset employed in the analysis consisted of 386 sample answers.

\section{Demographic Profile of the Respondents}

The following table shows the demographic profile of the respondents.

Table 1. Demographic Profile $(n=386)$

\begin{tabular}{llcc}
\hline & & Frequency & Percent \\
\hline \multirow{2}{*}{ Gender } & Male & 193 & 50.0 \\
& Female & 193 & 50.0 \\
& Single & 117 & 30.3 \\
Marital Status & Married & 264 & 68.4 \\
& Divorced & 4 & 1.0 \\
& Widow & 1 & .3 \\
Age Group & 21-30 years & 118 & 30.6 \\
& 31-40 years & 177 & 45.9 \\
Education & 41-50 years & 61 & 15.8 \\
& More than 50 years & 30 & 7.8 \\
& Master or equivalent & 94 & 24.4 \\
& M Phil or equivalent & 165 & 42.7 \\
Teaching Experience & Doctorate & 108 & 28.0 \\
& Post-Doc & 19 & 4.9 \\
& Below 1 year & 22 & 5.7 \\
& 1-3 years & 53 & 13.7 \\
& 7-9 years & 109 & 28.2 \\
Institute Category & 59 & 15.3 \\
& 10 years and above & 143 & 37.0 \\
& Rs. 25000 or below & 12 & 3.1 \\
& Rs. 25001 - Rs. & 116 & 30.1 \\
Monthly Income & 50000 & & \\
& Rs. 50001 - Rs. & 134 & 34.7 \\
& 100000 & 124 & 32.1 \\
& Above Rs. 100000 & 150 & 38.9 \\
& Private Sector & 236 & 61.1 \\
\hline
\end{tabular}

Source: Study Analysis 
The above table 1. has been based on 386 respondents of which $193(50 \%)$ were male, and 193 $(50 \%)$ were female. There were 117 (30.3\%) respondents were unmarried, $264(68.4 \%)$ respondents were married, $4(1 \%)$ respondents were divorced, and $1(0.3 \%)$ respondent was widowed. $118(30.6 \%)$ respondents were aged 21-30 years, 177 (45.9\%) respondents were 31-40 years old, $61(15.8 \%)$ respondents were $41-50$ years, and 30 (7.8\%) respondents were more than 50 years old. $94(24.4 \%)$ respondents had master's or equivalent education, $165(42.7 \%)$ respondents had M. Phil education, 108 (28\%) respondents were PhDs, and 19 (4.9\%) respondents were Post Doctorate. Moreover, 22 (5.7\%) respondents had below 1-year teaching experience, 53 (13.7\%) respondents had 1-3 years teaching experience, 109 (28.2\%) respondents had 4-6 years teaching experience, $59(15.3 \%)$ respondents had 7-9 years teaching experience, and $143(37 \%)$ respondents had 10 years and above teaching experience. Related to the monthly salary scale of the respondents, $12(3.1 \%)$ respondents earned Rs.25000 or below, $116(30.1 \%)$ respondents earned Rs.25001 - Rs.50000, 134 (34.7\%) respondents earned Rs.50001 - Rs.100000 and 124 (32.1\%) respondents received above Rs.100000 income. Lastly, 150 (38.9\%) study respondents were from public sector, while $236(61.1 \%)$ respondents belonged to private institutions.

\section{Measurement Model}

Table 2. Measurement Model

\begin{tabular}{llcccc}
\hline Variable & Items & Loadings & Alpha & CR & AVE \\
\hline \multirow{4}{*}{ Anxiety } & A1 & 0.787 & & & \\
& A3 & 0.775 & 0.784 & 0.861 & 0.607 \\
& A5 & 0.760 & & & \\
Extra role performance & ER1 & 0.794 & & & \\
& ER2 & 0.922 & & & \\
& ER3 & 0.911 & 0.915 & 0.941 & 0.798 \\
ER4 & 0.853 & & & \\
In-role performance & IR1 & 0.780 & & & \\
& IR2 & 0.817 & & & \\
& IR3 & 0.894 & 0.866 & 0.909 & 0.715 \\
Time Stress & IR4 & 0.886 & & & \\
& TS2 & 0.737 & & & \\
Work-Life Balance & TS3 & 0.769 & 0.718 & 0.826 & 0.543 \\
& TS4 & 0.682 & & & \\
& WLB1 & 0.781 & & & \\
& WLB3 & 0.929 & 0.718 & 0.826 & 0.543 \\
\hline
\end{tabular}

Source: Study Analysis 
The above table 2. demonstrates the outer loadings and its recommended threshold is given by Hair et al. (2011) that all the values must be higher than 0.70 for absolute acceptance. However, Hair et al. (2016) has recommended that when the values are less than 0.70 and higher than 0.40 then it can also be accepted based on convergent validity. Additionally, the table also contains CR and AVE and their recommended threshold as given by Hair et al. (2011) is that values of CR should be higher than 0.70 and values of AVE should be higher than 0.50 . The table has shown all correct values and therefore, the measurement model is validated.

\section{Discriminant Validity}

The following table 3 , illustrates the results of the HTMT ratio in discriminant validity.

Table 3. HTMT Ratio

\begin{tabular}{cccccc}
\hline & AN & ER & IR & TS & WLB \\
\hline AN & & & & \\
ER & 0.142 & & & \\
IR & 0.176 & 0.653 & & \\
TS & 0.729 & 0.229 & 0.184 & 0.361 \\
WLB & 0.316 & 0.093 & 0.151 & \\
\hline
\end{tabular}

$A N=$ Anxiety $; E R=$ Extra-role performance $; I R=I n$-role performance $; T S=$ Time stress $; W L B=$ Work-life balance

Source: Study Analysis

The above table 3. is based on the recommendation that all the HTMT values must be less than 0.85 for acceptance (Henseler et al., 2015). The table has shown all such values under the acceptance threshold and therefore, discriminant validity had been achieved using the HTMT ratio.

\section{Structural Model}

\section{Higher-Order Constructs}

It was found that employee behavior was significantly related to the extra-role performance $(0.904$, $\mathrm{P}<0.01)$ and the in-role performance $(0.878, \mathrm{P}<0.01)$. Furthermore, it was found that workplace stress was significantly related to anxiety $(0.895, \mathrm{P}<0.01)$ and time stress $(0.865, \mathrm{P}<0.01)$. 
Figure 2. PLS Algorithm Model

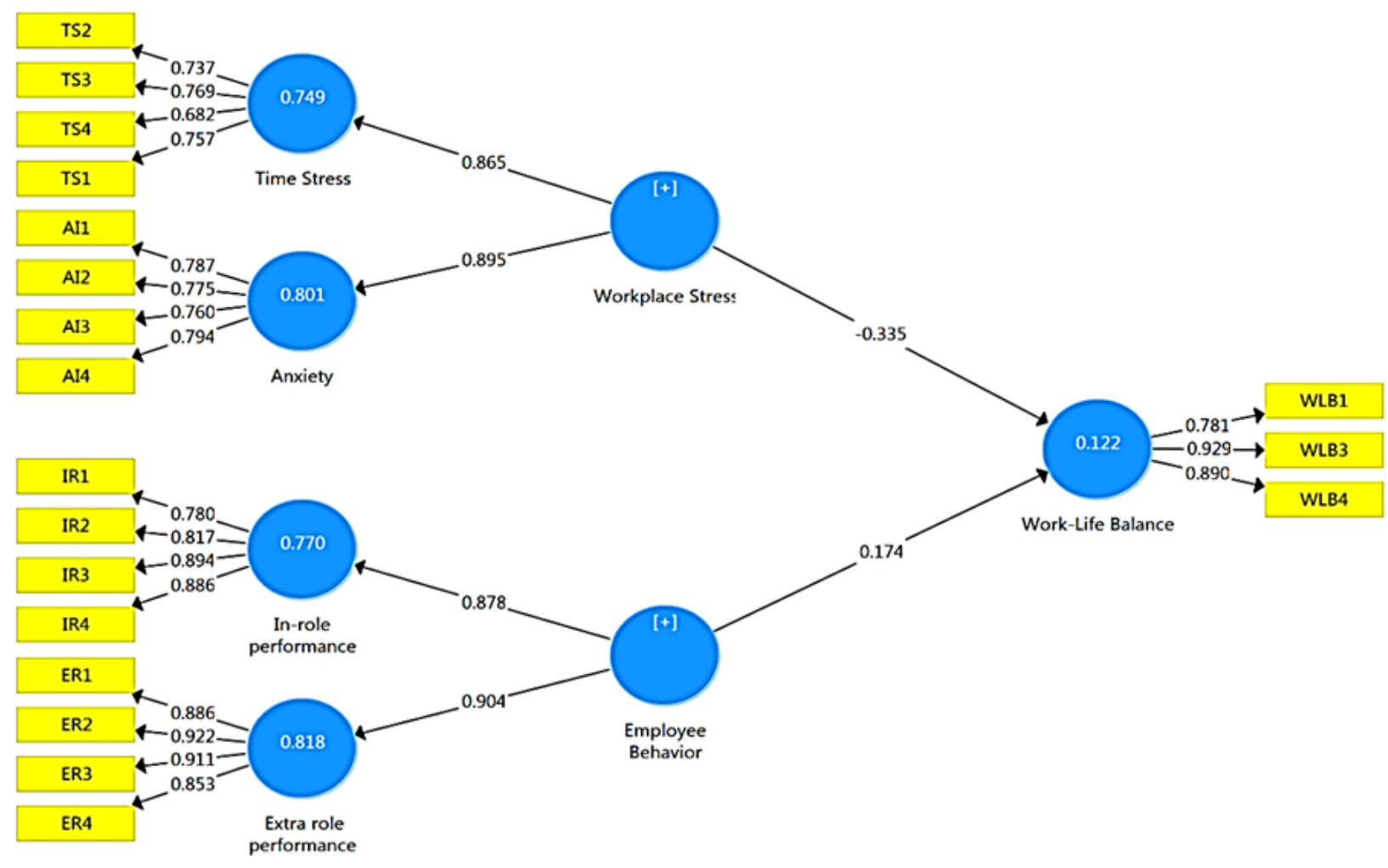

Source: Study Analysis

\section{Path Analysis}

The following table 4 . shows the results of hypothesis-testing using path analysis.

Table 4. Path Analysis

\begin{tabular}{lcccc}
\hline & Path Analysis & & & \\
& Estimate & Std. Dev. & T-Stats & Prob. \\
\hline Employee Behavior -> Work-Life Balance & 0.174 & 0.051 & 3.399 & 0.000 \\
Workplace Stress -> Work-Life Balance & -0.335 & 0.052 & 6.411 & 0.000 \\
\hline
\end{tabular}

$R$-Square $=0.122 ; Q$ Square $=0.088$

Source: Study Analysis

The above table illustrates that the employee behavior $(\beta=0.174, \mathrm{p}<0.001)$ has a positive and significant effect on work-life balance, respectively. Similarly, workplace stress $(B=-0.335, p<$ 0.001) has a negative and significant effect on work-life balance. 
Figure 3. PLS Bootstrapping Model

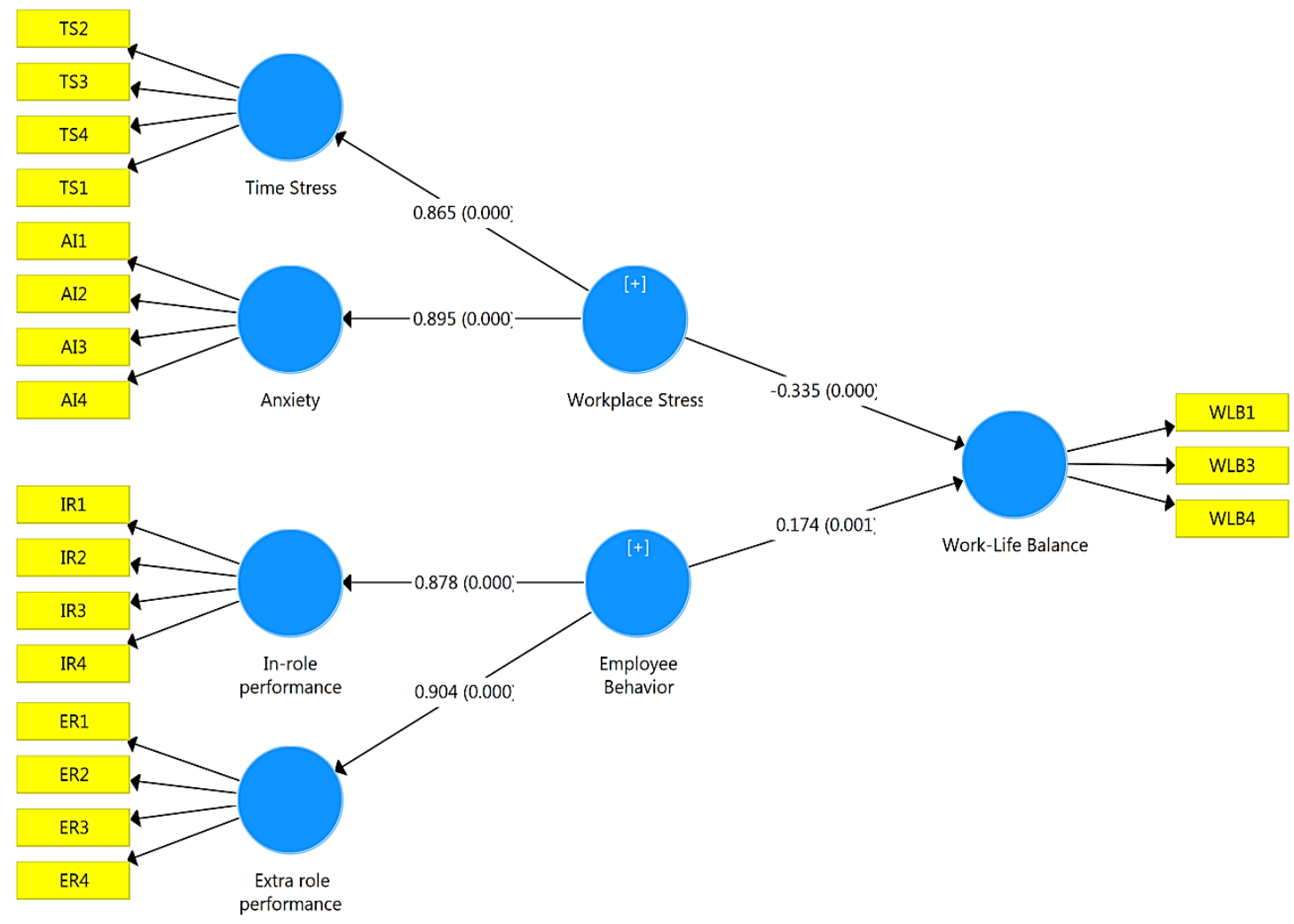

Source: Study Analysis

\section{Predictive Relevance}

Cohen (1988); Falk and Miller (1992) recommended R2 values of R2 to be equal or greater to 0.10 , with R2 of 0.26 being substantial, 0.13 as moderate and 0.02 as weak, hence, the R2 value was weak to moderate. This research has shown that work-life balance has been predicted by 12.2 percent. However, Q square has been found higher than absolute zero.

\section{DISCUSSION}

According to the findings, there is a substantial negative association between work stress and WLB. To put it another way, there is a substantial negative link between WLB and WS. That is, variations in one equation are strongly connected to variations in another (Zaheer et al., 2016). Relatively, Podsakoff et al. (2007) also found a significantly negative association between work stress and WLB. Workplace stress affects job satisfaction, workplace effectiveness, mental and physical health, absenteeism, and economic costs, as well as have a higher impact on families, all of which have an influence on workforce performance (Ross \& Vasantha, 2014). WLB is described 
as "pleasure and excellent functioning at work and home with the least amount of strain." As a result, it is sometimes defined as "the lack of excessive tension between work and non-work obligations" (Shankar \& Bhatnagar, 2010).

Manzoor et al. (2011) investigated the work stress and JS of Pakistani university professors and found that work is an important aspect of life and that displeasure with it has a negative influence on the quality of life. Besides, Winefield et al. (2003) conducted research and organized focus groups on occupational stress among Australian university teachers. They discovered more stress among academic workers than among other employees. Workplace stress hurts certain employees' personal and professional life, according to some employees. Bhatti et al. (2011) also investigated job stress among university professors and found that task burden, position ambiguity, managerial role, attainment compression, and interpersonal contact are all factors that contribute to workplace stress.

A survey by Sengupta and Sengupta (2018) further reported that Indian workers rate uncertain or inconsistent job requirements (40\%), poor staffing (lack of support, unequal workload or group performance) (38\%) and lack of work-life balance (38\%) as the top three causes of tension. Furthermore, Yusoff and Khan (2013) concluded that the list of stressors involved homework program, management structure, partnership with others, assignment instability, achievement pressure and workload, low pay issues due to student and career conflicts, lack of physical help, academic problems, instructor self-efficiency novices, job results, amount of students in college, marital status and experience, confusion of job outcomes e.g. organizational commitment and jobs.

Moreover, it was found that the effect of employee behavior on work-life balance was supported by Kalleberg (2009). Winefield et al. (2003) discovered that academic job tension is high due to the disparity between job demands and sensitivity. As both time and focus are required, academic staff involved in research and teaching will generate a contrasting scenario. Tiredness, sleeping problem, and concentration are the symptoms found among lecturers. These are more visible when more workload is expected to attract external research funds.

Education and adequate therapy failures contribute to the extent of stress at work when workers struggle to deal with difficult conditions (Jepson \& Forrest, 2006). Work overload is one of the 
most demanding tasks that employees face today (Anderson \& Pulich, 2001). Kyriacou (1987) assert that another stressor that influences well-being and success is favoritism. Klockars et al. (2007) stated that the lack of administrative support leads to fatigue, burnout, and work changes. Similarly, Billingsley (2004) argued that stress strikes teachers as they try to hold more sessions, paperwork, and more documents to pay for themselves (Imam et al., 2011) They concluded that long hours of work owing to increased workload may have an inverse impact on workplace satisfaction as this condition interferes with one's wellbeing at work and home. The inability to strike the right balance in terms of effort and compensation is strongly associated with the loss of task management and lack of energy to satisfy personal needs and dedication. The difference in both would often result in exhaustion, weak results, and a diminished quality of life (Goyal \& Arora, 2012).

In comparison when work management is tight, tight demand for work does not automatically result in tension. Alternatively, feelings of accomplishment and success will occur when expectations for work and job management are strong (Fernet et al., 2004). Brymer et al. (1991) similarly concluded that stress management systems that offer employees greater control over their job responsibilities play an important role in reducing stress. As Ryan and Deci (2001) argued that the psychological impact of managing job demands helps to reduce tension and is related to feelings of well-being and happiness. On the other hand, where workers have autonomy and control over their work schedules or the scope to choose specific working hours, this has a positive effect not only on work-life balance but also on the health and well-being of workers. Research carried out by (Beauregard \& Henry, 2009) indicates that those workers who were more positive to the initiatives of their employer to promote work-life balance have shown a much lower intention to leave the company, greater confidence in their institution, a tendency to suggest it as a place to work and greater overall job satisfaction. There is substantial evidence to conclude that neglect or loss of social care will contribute to poor health, whereas when it occurs it promotes wellbeing and acts as a shield against negative effects of stress (Wainwright \& Calnan, 2002). At the same time, career growth is a significant source of stress for university teachers, with the most challenging causes being the disparity between personal aspirations and university aspirations that lead to delayed career advancement, loss of social support, and a weak working climate (Ofoegbu \& Nwadiani, 2006). It is further reported in this context that teaching should be recognized as a 
technical occupation and that teachers should be encouraged to tackle inspiration, happiness, and stress-related problems (Pearson \& Moomaw, 2005).

\section{CONCLUSION}

This study aimed to identify the impact of workplace pressures and employees' behavior on impairing the WLB of workers and also to identify the internal and external factors affecting the WLB of workers in Karachi, Pakistan's HEIs. The results have revealed that employee behavior has a positive significant effect on work-life balance in private sector higher education institutes. The results of the comparison parametric test showed that there is a statistically significant and positive difference of opinion between the faculty members of private and public sector higher education institutes concerning the effect of employee behavior on work-life balance. Furthermore, the comparison results showed no difference of opinion between the faculty members of private and public sector higher education institutes regarding the effect of workplace stress on work-life balance. The study collected 386 responses of faculty members working in Karachi and analyzed the collected data using the PLS-SEM technique. The study provides significant suggestions to the managers of the higher education institutions in Karachi. Besides contributing to the theoretical importance of WLB, the paper also had certain limitations on a demographical level and many other aspects which can be incorporated in future studies.

Improving workplace satisfaction will improve overall wellbeing and general well-being. It can also help improve employee productivity, enthusiasm, and overall job satisfaction, resulting in better organizational results. Businesses should help employees do their work. If your employee struggles to find the optimal balance between work and leisure, try effective strategies for worklife balance. Firstly, the Human Resource department of the universities must be in the best position to promote workplace support and strategies to minimize interrelated stressors and develop workers' resilience. Secondly, a supervisor's help is more relevant to work-related issues than family support, just as a spouse's encouragement is more likely to be helpful to personal liferelated stress.

For potential work-life stressors and employee well-being, it could be advised to use personcentered stress management strategies. Examples include offering relaxation/care exercise courses, facilitating wellness and delivering facilities, such as gymnasiums, supporting safe living 
and healthier food decisions, and advice. Because it has been seen that high-stress levels rise in turnover and poor morale, HEIs need to be mindful of the possible negative consequences of stress at work.

Lastly, WLB is rated today as one of the most important attributes of the workforce second only to wages, and workers who believe they have a better work-life balance tend to work more than other staff who are overworked. These are some of the many ways by which managers can encourage work-life balance without jeopardizing productivity or efficiency at work.

Future studies must closely investigate the disparate impact on employee well-being of HRM activities since only some of them can play a beneficial role in coping with stress. On either hand, the facilitation of work-family change and the maintenance of a supportive partnership environment should be considered by HR administrators, as both could lead to tension reduction and towards the goal to minimize turnover. In addition to building an organizational culture that encourages workers to operate confidently, managers should consider concentrating their efforts on designing specialized services to facilitate family adaptation.

\section{Acknowledgement:}

The authors acknowledge the help provided by all stakeholders who played a role in completing this academic accomplishment.

\section{Author(s) Contribution:}

The main author of this study is solely responsible to conduct this research, from study conception and design, data collection, analysis and interpretation of results, and manuscript preparation. The second author has guided the main author as research supervisor to conduct this research. 


\section{REFERENCES}

Ahmad, A., Hussain, A., Saleem, M. Q., Qureshi, M. A. M., \& Mufti, N. A. (2015). Workplace stress: a critical insight of causes, effects and interventions. Tech J, 20, 45-55.

Anderson, P., \& Pulich, M. (2001). Managing workplace stress in a dynamic environment. The health care manager, 19(3), 1-10. Doi:https://doi.org/10.1097/00126450-20011903000002

Annink, A., Annink, A., Den Dulk, L., Den Dulk, L., Amorós, J. E., \& Amorós, J. E. (2016). Different strokes for different folks? The impact of heterogeneity in work characteristics and country contexts on the work-life balance among the self-employed. International Journal of Entrepreneurial Behaviour \& Research, 22(6), 880-902. Doi: https://doi.org/10.1108/IJEBR-04-2016-0127

Armstrong, G. S., Atkin-Plunk, C. A., \& Wells, J. (2015). The relationship between work-family conflict, correctional officer job stress, and job satisfaction. Criminal justice and behaviour, 42(10), 1066-1082. Doi: https://doi.org/10.1177/0093854815582221

Ayudhya, U. C. N., Prouska, R., \& Beauregard, T. A. (2017). The Impact of Global Economic Crisis and Austerity on Quality of Working Life and Work-Life Balance: A Capabilities Perspective. European Management Review. Doi: https://doi.org/10.1111/emre.12128

Beauregard, T. A., \& Henry, L. C. (2009). Making the link between work-life balance practices and organizational performance. Human Resource Management Review, 19(1), 9-22. Doi: https://doi.org/doi.org/10.1016/j.hrmr.2008.09.001

Bhatti, N., Hashmi, M. A., Raza, S. A., Shaikh, F. M., \& Shafiq, K. (2011). Empirical analysis of job stress on job satisfaction among university teachers in Pakistan. International Business Research, 4(3), 264. Doi: https://doi.org/10.5539/ibr.v4n3p264

Billingsley, B. S. (2004). Special education teacher retention and attrition: A critical analysis of the research literature. The Journal of Special Education, 38(1), 39-55. Doi: https://doi.org/10.1177/00224669040380010401

Brotheridge, C. M., \& Lee, R. T. (2002). Testing a conservation of resources model of the dynamics of emotional labor. Journal of occupational health psychology, 7(1), 57. Doi: https://doi.org/10.1037/1076-8998.7.1.57

Brymer, R. A., Perrewe, P. L., \& Johns, T. R. (1991). Managerial job stress in the hotel industry. International Journal of Hospitality Management, 10(1), 47-58. Doi: https://doi.org/10.1016/0278-4319(94)90022-1 
Chang, X., Zhou, Y., Wang, C., \& de Pablos Heredero, C. (2017). How do work-family balance practices affect work-family conflict? The differential roles of work stress. Frontiers of Business Research in China, 11(1), 8. Doi: https://doi.org/10.1186/s11782-017-0008-4

Chawla, D., \& Sondhi, N. (2011). Assessing work-life balance among Indian women professionals. Indian Journal of Industrial Relations, 341-352.

Cohen, J. (1988). Statistical power analysis for the behavioural sciences (2nd ed.). Lawrence Erlbaum Associates. Doi:https://doi.org/10.4324/9780203771587

Colligan, T. W., \& Higgins, E. M. (2006). Workplace stress: Etiology and consequences. Journal of workplace behavioural health, 21(2), 89-97. Doi:https://doi.org/10.1300/J490v21n02_07

Direnzo, M. S., Greenhaus, J. H., \& Weer, C. H. (2015). Relationship between protean career orientation and work-life balance: A resource perspective. Journal of Organizational Behaviour, 36(4), 538-560. Doi: https://doi.org/10.1002/job.1996

Dryson, E. W., Scragg, R. K., Metcalf, P. A., \& Baker, J. R. (1996). Stress at work: an evaluation of occupational stressors as reported by a multicultural New Zealand workforce. International Journal of occupational and environmental health, 2(1), 18-25. Doi: https://doi.org/10.1179/OEH.1996.2.1.18

Duong, M. T., Hussain, I. A., \& Subramaniam, A. (2020). Job Stress, Co-Worker Support, Role Expectation Conflict and Work-Life Balance Among Working Women: A Quantitative study on Multinational Companies in Vietnam. Doi: https://doi.org/10.1186/s13033-0160078-2

Falk, R. F., \& Miller, N. B. (1992). A primer for soft modeling (1st ed.). University of Akron Press.

Ferguson, M. (2012). You cannot leave it at the office: Spillover and crossover of coworker incivility. Journal of Organizational Behaviour, 33(4), 571-588. Doi: https://doi.org/10.1002/job.774

Fernet, C., Guay, F., \& Senécal, C. (2004). Adjusting to job demands: The role of work selfdetermination and job control in predicting burnout. Journal of Vocational Behaviour, 65(1), 39-56. Doi: https://doi.org/10.1016/S0001-8791(03)00098-8

Freedy, J. R., \& Hobfoll, S. E. (1994). Stress inoculation for reduction of burnout: A conservation of resources approach. Anxiety, stress and coping, 6(4), 311-325. Doi: https://doi.org/10.1080/10615809408248805 
Ghosh, R. (2016). A Study on Work-Life Balance of Employees in Pharmaceutical Industry with Special Reference to Kolkata City. Globsyn Management Conference 2015,

Giauque, D., Anderfuhren-Biget, S., \& Varone, F. (2019). Stress and turnover intents in international organizations: social support and work-life balance as resources. The International Journal of Human Resource Management, 30(5), 879-901. Doi: https://doi.org/10.1080/09585192.2016.1254105

Gillespie, N. A., Walsh, M., Winefield, A. H., Dua, J., \& Stough, C. (2001). Occupational stress in universities: Staff perceptions of the causes, consequences and moderators of stress. Work \& Stress, 15(1), 53-72. Doi: https://doi.org/10.1080/02678370117944

Goyal, M., \& Arora, S. (2012). Harnessing work: family life balance among teachers of educational institutions. International Journal of Applied Services Marketing Perspectives, 1(2), 170. Doi: https://doi.org/10.5958/j.2231-458X.4.3.010

Gudep, V. K. (2019). An Empirical Study of The Relationships between The Flexible Work Systems (FWS), Organizational Commitment (OC), Work-Life Balance (WLB) and Job Satisfaction (JS) For The Teaching Staff In The United Arab Emirates (UAE). International Journal of Management, 10(5).

Haar, J. M., Sune, A., Russo, M., \& Ollier-Malaterre, A. (2019). A cross-national study on the antecedents of work-life balance from the fit and balance perspective. Social Indicators Research, 142(1), 261-282. Doi: https://doi.org/10.1007/s11205-018-1875-6

Hair, J. F., Hult, G. T. M., Ringle, C., \& Sarstedt, M. (2016). A primer on partial least squares structural equation modelling (PLS-SEM) (2nd ed.). SAGE Publications.

Hair, J. F., Matthews, L. M., Matthews, R. L., \& Sarstedt, M. (2017). PLS-SEM or CB-SEM: updated guidelines on which method to use. International Journal of Multivariate Data Analysis, 1(2), 107-123. Doi: https://doi.org/10.1504/IJMDA.2017.087624

Hair, J. F., Ringle, C. M., \& Sarstedt, M. (2011). PLS-SEM: Indeed a silver bullet. Journal of Marketing Theory and Practice, 19(2), 139-152. Doi: https://doi.org/10.2753/MTP10696679190202

Hair, J. F., Sarstedt, M., Hopkins, L., \& Kuppelwieser, V. G. (2014). Partial least squares structural equation modelling (PLS-SEM) An emerging tool in business research. European Business Review, 26(2), 106-121. Doi: https://doi.org/10.1108/EBR-10-2013-0128 
Hayes, B., Douglas, C., \& Bonner, A. (2015). Work environment, job satisfaction, stress and burnout among haemodialysis nurses. Journal of nursing management, 23(5), 588-598. Doi: https://doi.org/10.1111/jonm.12184

Henseler, J., Ringle, C. M., \& Sarstedt, M. (2015). A new criterion for assessing discriminant validity in variance-based structural equation modelling. Journal of the academy of marketing science, 43(1), 115-135. Doi: https://doi.org/10.1007/s11747-014-0403-8

Hobfoll, S. E. (2001). The influence of culture, community, and the nested-self in the stress process: Advancing conservation of resources theory. Applied psychology, 50(3), 337-421. Doi: https://doi.org/10.1111/1464-0597.00062

Hobfoll, S. E. (2011). Conservation of resources theory: Its implication for stress, health, and resilience. The Oxford handbook of stress, health, and coping, 127-147. Doi: https://doi.org/10.1093/oxfordhb/9780195375343.013.0007

Husin, N. A., Ghazali, A. S. M., Abdullah, N., \& Hadi, M. I. B. A. (2017). Work-life balance of Malaysian lecturers. Australian Academy of Business and Economics Review, 4(1), 43-49.

Imam, H., Qureshi, T. M., \& Khan, M. A. (2011). The retrenchment effect on job performance with mediating effect of work-life balance. African Journal of Business Management, 5(21), 8642. Doi: https://doi.org/10.5897/AJBM11.1297

Jepson, E., \& Forrest, S. (2006). Individual contributory factors in teacher stress: The role of achievement striving and occupational commitment. British Journal of Educational Psychology, 76(1), 183-197. Doi: https://doi.org/10.1348/000709905X37299

Kalleberg, A. L. (2009). Precarious work, insecure workers: Employment relations in transition. American sociological review, $74(1), \quad$ 1-22. Doi: https://doi.org/10.1177/000312240907400101

Karkoulian, S., Srour, J., \& Sinan, T. (2016). A gender perspective on work-life balance, perceived stress, and locus of control. Journal of Business Research, 69(11), 4918-4923. Doi: https://doi.org/10.1016/j.jbusres.2016.04.053

Klockars, C. B., Ivković, S. K., \& Haberfeld, M. R. (2007). Enhancing police integrity. Springer.

Krishnaveni, R., \& Deepa, R. (2013). Controlling common method variance while measuring the impact of emotional intelligence on well-being. Vikalpa, 38(1), 41-48. Doi: https://doi.org/10.1177/0256090920130104

Kumar, S., \& Phrommathed, P. (2005). Research methodology. Springer. 
Kumari, L. (2012). Employees perception on work life balance and its relation with job satisfaction in Indian public sector banks. International Journal of Engineering and Management Research, 2(2), 1-13. Doi: https://doi.org/10.17148/IARJSET.2016.31108

Kundaragi, P. B., \& Kadakol, A. (2015). Work Stress of Employee: A Literature Review. International Journal of Advance Research and Innovative Ideas in Education, 1(3), 1823. Doi: https://doi.org/10.19080/ASM.2018.02.555586

Kyriacou, C. (1987). Teacher stress and burnout: An international review. Educational research, 29(2), 146-152. Doi: https://doi.org/10.1080/0013188870290207

Le, H., Newman, A., Menzies, J., Zheng, C., \& Fermelis, J. (2020). Work-life balance in Asia: A systematic review. Human Resource Management Review, 100766. Doi: https://doi.org/10.1016/j.hrmr.2020.100766

Lestari, N. D., \& Rizkiyah, N. (2021). The Workplace Stress and its Related Factors among Indonesian Academic Staff. Open Access Macedonian Journal of Medical Sciences, 9(T4), 70-76. Doi: https://doi.org/10.3889/oamjms.2021.5802

Manzoor, M. U., Usman, M., \& Naseem, M. A. (2011). A Study of Job Stress and Job Satisfaction among Universities Faculty in Lahore, Pakistan. Global Journal of Management and Business Research, 11(9).

McCarthy, A., Darcy, C., \& Grady, G. (2010). Work-life balance policy and practice: Understanding line manager attitudes and behaviours. Human Resource Management Review, 20(2), 158-167. Doi: https://doi.org/10.1016/j.hrmr.2009.12.001

Miller, G. E., Buckholdt, D. R., \& Shaw, B. (2008). Introduction: Perspectives on stress and work. Journal of Human Behaviour in the Social Environment, 17(1-2), 1-18. Doi: https://doi.org/10.1080/10911350802165403

Neumann, J. L., Mau, L.-W., Virani, S., Denzen, E. M., Boyle, D. A., Boyle, N. J., Dabney, J., De KeselLofthus, A., Kalbacker, M., \& Khan, T. (2017). Burnout, Moral Distress, Work-Life Balance and Career Satisfaction among Hematopoietic Cell Transplantation Professionals. Biology of Blood and Marrow Transplantation. Doi: https://doi.org/doi: 10.1016/j.bbmt.2017.11.015.

Newman, I., \& Benz, C. R. (1998). Qualitative-quantitative research methodology: Exploring the interactive continuum. SIU Press. 
Niessen, C., Mäder, I., Stride, C., \& Jimmieson, N. L. (2017). Thriving when exhausted: The role of perceived transformational leadership. Journal of Vocational Behaviour, 103, 41-51. Doi: https://doi.org/10.1016/j.jvb.2017.07.012

Noor, K. M. (2011). Work-life balance and intention to leave among academics in Malaysian public higher education institutions. International journal of business and social science, 2(11). Doi: https://doi.org/10.6007/IJARBSS/v7-i13/3181

Ofoegbu, F., \& Nwadiani, M. (2006). Level of Perceived Stress Among Lectures in Nigerian Universities. Journal of instructional psychology, 33(1).

Othman, C. N., Lamin, R. A. C., \& Othman, N. (2014). Occupational stress index of Malaysian university workplace. Procedia-Social and Behavioural Sciences, 153, 700-710. Doi: https://doi.org/10.1016/j.sbspro.2014.10.101

Pearson, L. C., \& Moomaw, W. (2005). The relationship between teacher autonomy and stress, work satisfaction, empowerment, and professionalism. Educational research quarterly, 29(1), 38-54. Doi: https://doi.org/10.1080/2331186X.2021.1898737

Peffers, K., Tuunanen, T., Rothenberger, M. A., \& Chatterjee, S. (2007). A design science research methodology for information systems research. Journal of management information systems, 24(3), 45-77. Doi: https://doi.org/10.2753/MIS0742-1222240302

Podsakoff, N. P., LePine, J. A., \& LePine, M. A. (2007). Differential challenge stressor-hindrance stressor relationships with job attitudes, turnover intentions, turnover, and withdrawal behaviour: a meta-analysis. Journal of applied psychology, 92(2), 438. Doi: https://doi.org/10.1037/0021-9010.92.2.438

Podsakoff, P. M., MacKenzie, S. B., Lee, J.-Y., \& Podsakoff, N. P. (2003). Common method biases in behavioural research: A critical review of the literature and recommended remedies. Journal of applied psychology, 88(5), 879-903. Doi: https://doi.org/10.1037/0021-9010.88.5.879

Rahimić, Z., Resić, E., \& Kožo, A. (2012). Determining the level of management competencies in the process of employee motivation. Procedia-Social and Behavioural Sciences, 41, 535543. Doi: https://doi.org/10.1016/j.sbspro.2012.04.066

Razak, M., Yusof, N. M., Azidin, R. A., Latif, M., \& Ismail, I. (2014). The impact of work stress towards work life balance in Malaysia. International Journal of Economics, Commerce and Management, 2(11), 1-16. 
Rehman, S., \& Azam Roomi, M. (2012). Gender and work-life balance: a phenomenological study of women entrepreneurs in Pakistan. Journal of Small Business and Enterprise Development, 19(2), 209-228. Doi: https://doi.org/10.1108/14626001211223865

Ross, D. S., \& Vasantha, S. (2014). A conceptual study on the impact of stress on work-life balance. Sai Om Journal of Commerce \& Management: A Peer-Reviewed National Journal (Online ISSN 2347-7563), 1(2), 61-65.

Ryan, R. M., \& Deci, E. L. (2001). On happiness and human potentials: A review of research on hedonic and eudaimonic well-being. Annual review of psychology, 52(1), 141-166. https://doi.org/10.1146/annurev.psych.52.1.141

Saeed, K., \& Farooqi, Y. A. (2014). Examining the relationship between work life balance, job stress and job satisfaction among university teachers (A case of university of Gujrat). International Journal of Multidisciplinary Sciences and Engineering, 5(6), 9-14. Doi: https://doi.org/10.6007/IJARPED/v3-i4/965

Schepers, J., Falk, T., Ruyter, K. d., Jong, A. d., \& Hammerschmidt, M. (2012). Principles and principals: do customer stewardship and agency control compete or complement when shaping frontline employee behaviour? Journal of Marketing, 76(6), 1-20. Doi: https://doi.org/10.1509/jm.11.0112

Selye, H. (1956). The Stress of Life. McGraw-Hill.

Sengupta, M., \& Sengupta, N. (2018). Enshrining The Spirit of CSR: Indian Automobile Industry, $6(01)$.

Senol-Durak, E., Durak, M., \& Gencoz, T. (2021). Job satisfaction, and burnout as mediators of trait anger, work stress, positive and negative affect in a sample of Turkish correctional officers. The Journal of Forensic Psychiatry \& Psychology, 1-21. Doi: https://doi.org/10.1080/14789949.2021.1884738

Shankar, T., \& Bhatnagar, J. (2010). Work life balance, employee engagement, emotional consonance/dissonance \& turnover intention. Indian Journal of Industrial Relations, 7487. Doi: https://doi.org/10.2307/25741098

Shukla, A., \& Srivastava, R. (2016). Development of short questionnaire to measure an extended set of role expectation conflict, coworker support and work-life balance: The new job stress scale. Cogent business \& management, 3(1), 1. Doi: https://doi.org/10.1080/23311975.2015.1134034 
Silva, C. T., Hakim, M. P., Zanetta, L. D. A., Pinheiro, G. S. D. D., Gemma, S. F. B., \& da Cunha, D. T. (2021). Burnout and food safety: Understanding the role of job satisfaction and menu complexity in foodservice. International Journal of Hospitality Management, 92, 102705. Doi: https://doi.org/doi.org/10.1016/j.ijhm.2020.102705

Singh, S. (2013). Work life balance: A literature review. Global Journal of Commerce \& Management Perspective, 2(3), 84-91. Doi: https://doi.org/10.6084/m9.figshare.12016704

Tabachnick, B. G., \& Fidell, L. S. (2007). Using multivariate statistics (7th ed.). Allyn \& Bacon/Pearson Education.

Thamrin, M., \& Riyanto, S. (2020). The Effect of Work Motivation, Work Environment, and Work Life Balance on Employee Performance at PT. AngkasaPura I (Persero) Sultan Aji Muhammad Sulaiman Sepinggan Airport-Balikpapan. IOSR Journal of Dental and Medical Sciences, 19(6), 40-47. Doi: https://doi.org/10.9790/0853-1906044047

Wainwright, D., \& Calnan, M. (2002). Work stress: The making of a modern epidemic. McGrawHill Education (UK).

Warraich, U. A., Ahmed, R. R., Nawaz, A., \& Khoso, I. (2014). Impact of Stress on Job Performance: An Empirical Study of the Employees of Private Sector Universities of Karachi, Pakistan.

Winefield, A. H., Gillespie, N., Stough, C., Dua, J., Hapuarachchi, J., \& Boyd, C. (2003). Occupational stress in Australian university staff: Results from a national survey. International Journal of Stress Management, 10(1), 51. Doi: https://doi.org/10.1037/10725245.10.1.51

Wirtz, A., Nachreiner, F., \& Rolfes, K. (2011). Working on Sundays-effects on safety, health, and work-life balance. Chronobiology International, 28(4), 361-370. Doi: https://doi.org/10.3109/07420528.2011.565896

Wong, K. K.-K. (2013). Partial least squares structural equation modeling (PLS-SEM) techniques using SmartPLS. Marketing Bulletin, 24(1), 1-32.

Yadav, R. K., \& Yadav, S. S. (2014). Impact of work life balance and stress management on job satisfaction among the working women in public sector banks. International Letters of Social Humanistic Sciences, 26, 63-70. Doi: https://doi.org/10.18052/www.scipress.com/ILSHS.26.63

Yao, Y.-H., Fan, Y.-Y., Guo, Y.-X., \& Li, Y. (2014). Leadership, work stress and employee behaviour. Chinese Management Studies, 8(1), 109-126. Doi: https://doi.org/10.1108/CMS-04-2014-0089 
Yusoff, R. M., \& Khan, F. (2013). Stress and burnout in the higher education sector in Pakistan: A systematic review of literature. Research Journal of Recent Sciences ISSN(2277), 2502.

Zaheer, A., Islam, J. U., \& Darakhshan, N. (2016). Occupational Stress and Work-Life Balance: A Study of Female Faculties of Central Universities in Delhi, India. Journal of Human Resource Management, 4(1), 1-5. Doi: https://doi.org/10.11648/j.jhrm.20160401.11 